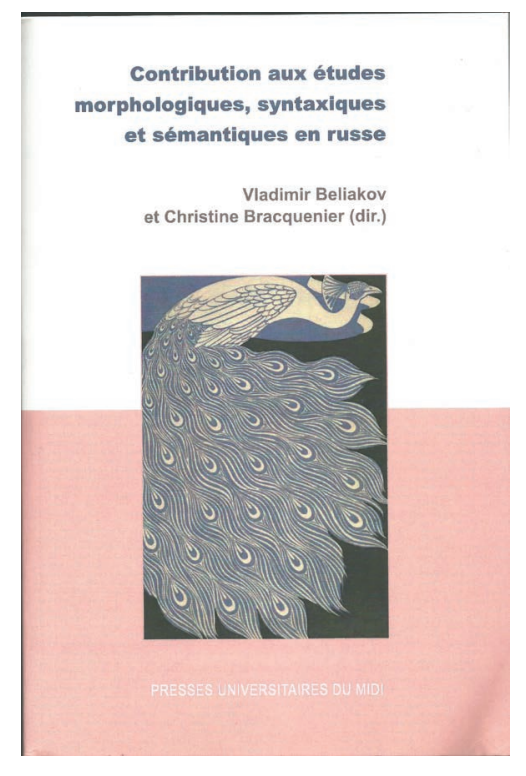

В.М. Амеличева (Москва, Россия)

Contribution aux études morphologiques, syntaxiques et sémantiques en russe.

Vladimir Beliakov et Christine Bracquenier (dir.). Toulouse: Presses Universitaires du Midi, 2017. 246 p. / Исследования по морфологии, синтаксису и семантике русского языка: Сб. статей / Под ред. Владимира Белякова и Кристин Бракенье. Тулуза: Presses Universitaires du Midi, 2017. 246 с.

V.M. Amelicheva (Moscow, Russia)

\title{
Contribution to Morphological, Syntactic and Semantic Studies in Russian / Eds.: Vladimir Belyakov and Christine Bracquenier. Tulouse: Presses Universitaires du Midi, 2017. 246 p.
}

Сборник «Contribution aux études morphologiques, syntaxiques et sémantiques en russe», опубликованный в 2017 г. издательством Университета Тулузы, включает двенадцать статей французских русистов. В числе авторов как наши бывшие соотечественники (Сергей Сахно, Татьяна Боттино, Ольга Артюшкина, Ирина Кор Шаин, Наталья Берницкая и другие), так и видные русисты-французы (Стефан Вьелар, Робер Руде, Тьери Рюшо). Можно констатировать, что составителям сборника (Владимиру Белякову и Кристин Бракенье) удалось собрать группу специализирующихся в разных областях авторов, что позволит читателю составить достаточно полное представление о сфере интересов и методологических принципах современной французской русистики. На первый взгляд сборник может показаться пестрым и тематически разнородным, однако при более внимательном прочтении становится ясно, что все исследования строятся на общих методических принципах: использование корпусного материала (тут нельзя не отметить роль Национального корпуса русского языка - НКРЯ - как ценнейшего общедоступного инструмента), комплексный подход к его анализу, учитывающий явления морфологического, синтаксического и семантического порядка, углубление теоретической основы исследований за счет использования, наряду с трудами классиков отечественного языкознания, работ франкоязычных, англоязычных и других зарубежных авторов. Интересно решение авторов-составителей предложить читателю единую библиографию в конце сборника вместо привычных отдельных списков в конце каждой статьи; как представляется, этот раздел имеет самостоятельную ценность, по сути 
представляя собой качественную компактную подборку важнейших исследований в области русистики, включающую как классические труды, так и последние работы отечественных и зарубежных авторов.

Остановимся подробнее на содержании отдельных статей, вошедших в рецензируемый сборник.

Статья Ольги Артюшкиной из Университета Экс-Марсель «Семантико-синтаксические особенности редупликативных глагольных конструкций с отрицанием: “спать не спит, но плакать не плачет”» («Sémantique et syntaxe des constructions verbales en écho avec la négation: “спать не спит, но плакать не плачет”») наглядно демонстрирует неразрывную связь между семантикой, синтаксисом, морфологией и прагматикой. Последовательно рассматривая корпусный материал, автор устанавливает связь между разными значениями одной и той же синтаксической конструкции (знать не знаю, ведать не ведаю; спать не спалось; читать не читает, только прикорнет с книжечкой; вы и обедать-то не обедали) и разными типами отрицания. Так, во фразеологизмах типа знать не знаю, ведать не ведаю редупликативная конструкция соответствует полному отрицанию, в уступительно-противительных фразеосхемах типа Читать ее статью я не читал, а посмотреть посмотрел отрицается вероятный факт, а при наличии иерархических отношений в семантике глаголов можно говорить о градуированном отрицании: Плакать не плачет, но похнычет бывало.

Статья Владимира Белякова из Университета Тулузы «Выражение значения понимания русскими глаголами» («La dénomination du comprendre à travers les verbes russes») представляет собой исследование в области глагольной полисемии с позиций когнитивной семантики. Отталкиваясь от трактовки понимания Дж. Лакоффа (ПОНИМАТЬ - ЭТО СХВАТЫВАТЬ и ПОНИМАТЬ — ЭТО ВИДЕТЬ), авТор исследует особенности семантики порядка тридцати русских глаголов понимания (понимать, разбираться, осознать, осмьслить, уяснить, постичь, разгадать, соображать, усматривать, видеть, уловить, раскусить и др.) и распределяет их по пяти семантическим классам: глаголы рассуждения, глаголы визуального восприятия, глаголы уяснения, глаголы оценки и интерпретации, глаголы физического воздействия и перемещения. Это позволяет ему дополнить классификацию Дж. Лакоффа новыми концептуальными метафорами: ПОНИМАТЬ - ЭТО ОТКРЫВАТЬ, ПОНИМАТЬ - ЭТО УСТАНАВЛИВАТЬ, ПОНИМАТЬ - ЭТО ОСВЕЩАТЬ, ПОНИМАТЬ - ЭТО ДВИГАТЬСЯ.

В статье Натальи Берницкой из Университета Париж-Сорбонна с несколько провокационным названием «Винни-Пух ходил в гости к Пятачку. Вернулся ли он домой? Проблема двунаправленных глаголов» («Винни-Пух ходил в гости к Пятачку. Вернулся ли он домой? Problème de l'aller-retour») представлен новый взгляд на русские двунаправленные глаголы с общефактическим значением типа ходить, ездить, открывать, брать (Вы открывали окно сегодня? Я брал эту книгу в библиотеке). Автор полемизирует с распространенной во французской русистике точкой зрения, согласно которой такие глаголы обозначают движение «туда и обратно». На материале НКРЯ Н. Берницкая показывает, что в зависимости от контекста глаголы двунаправленного движения могут иметь общефактическое, конкретно-фактическое или неограниченно-кратное значение, причем их интерпретация относится скорее к сфере прагматики, нежели семантики.

Татьяна Боттино из Национального института восточных языков и цивилизаций (INALCO, Париж) рассматривает функционирование наречия подряд в статье 
«От одного процесса к другому. Последовательность в русском языке на примере наречия подряд» («D'un procès l'autre. La consécution en russe vue à travers l'emploi de l'adverbe подряд»). Учитывая семантические, синтаксические, прагматические и просодические характеристики наречия, возможности его замены на близкие по значению конструкции и лексемы ( $N$ раз подряд / $N$ раз / $N$-жды), автор показывает, что подряд в русском языке может использоваться как в качестве наречия места, времени или образа действия (в синтагматическом плане), так и в качестве дискурсивного слова (в парадигматическом плане).

Кристин Бракенье из Университета Лилля в статье «Сирконстант: морфосинтаксис или семантика?» («Le circonstant, un concept morphosyntaxique ou sémantique?») предлагает обзор теоретических подходов к понятиям «сирконстант», «обстоятельство», «complément circonstanciel» в русской и французской лингвистической традиции, от грамматики Пор-Руаяля и М.В. Ломоносова до современных авторов. Избранный автором метод диахронического терминологического анализа как нельзя лучше отражает эволюцию лингвистических взглядов: от чисто морфологического, частеречного подхода (отождествление «обстоятельства» и «наречия» восходит к Античности, но находит свое отражение и у современных авторов, использующих термин «адвербиал», в частности у П. Ле Гоффика) к синтаксическому подходу Л. Теньера и А.М. Пешковского и комплексным семантико-синтаксическим концепциям современных авторов. Гиперонимический метатермин «сирконстант», по мысли К. Бракенье, делает акцент на роли исследуемой единицы в рамках высказывания и наиболее удачным образом охватывает все три измерения: морфологию, синтаксис и семантику.

В статье Ирины Кор Шаин из Университета Лазурного берега «Русские конструкции с verba sonandi, ассоциирующимися с животными» («Les constructions russes avec les verba sonandi associés aux animaux») с позиций лингвистики конструкций рассматриваются метафорические употребления звукоподражательных глаголов типа ржать, кудахтать, куковать, чирикать, рычать, иипеть и т. п. Автор выделяет среди них две основные группы: глаголы, характеризующие особенности человеческой речи, прежде всего ее агрессивный характер, и глаголы, обозначающие неприятные физические или психологические состояния (типа зудеть). Отдельно отмечен глагол лаяться как единственный, претерпевающий морфологические изменения в метафорическом употреблении. Для прочих глаголов, по заключению автора, морфосинтаксическая и аргументная структура определяется семантикой конструкции.

Фабио Монтермини из Университета Тулузы рассматривает русские сложносокращенные слова типа автопром, капстрана, политотдел с точки зрения конструкционной морфологии в статье «Русские сложносокращенные слова в лексематико-конструкционной модели морфологии» («Les composés abrégés du russe dans un modèle lexématique et constructionnel de la morphologie»). Автор не только классифицирует подобные композиты по способу образования, особо выделяя устойчивые аффиксоиды, такие как ин- (< иностранный) или юр- (< юридический), но и обращает внимание на роль экстраграмматических, в частности прагматических, факторов в их семантической интерпретации.

Статья Павла Орлова из Университета Тулузы «Способы выражения меронимии в русском языке» («L'expression de la méronymie en russe») представляет собой многоаспектное исследование способов выражения отношений «часть / целое» на синтаксическом, лексическом и словообразовательном уровнях. Основываясь на 
семантической типологии меронимических отношений М. Орнага, автор оценивает допустимость различных конструкций с участием меронима и холонима и приходит к выводу, что явление меронимии поддается анализу в рамках теории прототипов, причем прототипическим видом отношений являются отношения «элемент / совокупность». Именно они могут использоваться в максимально широком наборе разных конструкций (скрипачи оркестра; В оркестре есть скрипачи; Скрипачи - это часть оркестра). Прочие виды меронимических отношений обладают дополнительными характеристиками, накладывающими ограничения на использование в разных видах конструкций.

Статья Робера Руде из Университета Лиона «Наличие или отсутствие ecmь в предложениях экзистенциального типа» («Présence ou absence de ecmb dans les propositions de type existentiel») посвящена сопоставительному анализу экзистенциальных, идентификационных, атрибутивных, событийных, квантитативных предложений с $y$-посессором, включающих или не включающих личную форму глагола быть: У нее седые волосы / У нее есть седые волосы; У нас снег / У нас есть снег и т. п. Основываясь на наблюдениях О.Н. Селиверстовой, автор анализирует аргументативные значения предложений с элементом есть и без него (Зачем мне куда-то ехать? У меня есть дача / Я не могу ехать. У меня дача; Он ходить не может, у него нога / *у него есть нога), заключая, что именно наличие элемента есть доказывает собственно экзистенциальный характер высказывания.

В статье Тьери Рюшо из Университета Кан-Нормандия «Демонстративы в текстовой когезии в современном русском языке» («Les démonstratifs dans la cohésion textuelle en russe contemporain») подробно рассматриваются приименные демонстративы этот / тот на корпусном материале: отмечается их функциональная близость к французскому определенному артиклю, возможность их сочетания с частицами вон / вот, особенности их анафорического и дейктического употребления, «анамнезические» контексты с отсылкой к индивидуальной или коллективной памяти, возможность их постпозиции. Подчеркивается особая роль детерминативов в обеспечении текстового единства и необходимость более полного понимания механизмов референции для дискурсивного анализа.

Сергей Сахно из Университета Париж-Нантер рассматривает русские связочные глаголы в статье «Что представляют собой эти глаголье? versus Чем являются эти глагольь? Семантика и функционирование русских связочных глаголов являться, представлять собой (из себя) и являть собой (из себя): схемы грамматикализации» («Что представляют собой эти глаголье? versus Чем являются эти глагольл? La sémantique et le fonctionnement copulaire des verbes russes являться, представлять собой (из себя) еt являть собой (из себя): schémas de grammaticalisation»). Последовательно разбирая функционирование указанных глаголов в синхронии и эволюцию их значений в диахронии, автор констатирует существование двух осей их грамматикализации в связочном употреблении в рамках сложного семантического поля, ограниченного двумя крайними точками: «быть» и «казаться». Если первая ось соответствует «полноценной утвердительной модальности», т. е. стабилизации отношений между полюсами «быть» и «казаться» (являться, являть собой / из себя), то вторая указывает на «слабо выраженную утвердительную модальность», или проблематизацию отношений между полюсами (представляться, представлять собой / из себя).

Наконец, в статье Стефана Вьелара из Университета Париж-Сорбонна «Новые заметки об исторической фразеологии русского языка: прозрачность и препят- 
ствия» («Nouvelles remarques sur la phraséologie hystorique du russe: la transparence et l'obstacle») в центре внимания оказываются глагольные речения древне- и старорусского языка с глаголами дати и взяти. В семантическом отношении автор делит их на прозрачные (дати слово, дати на поруку), полупрозрачные (взяти дань и судъ) и непрозрачные (взяти рядъ, дати плечи, горло дати / тратити), отмечая такие характерные для этих фразеологизмов явления, как вариативность, омонимия, внутренняя полисемия и синонимия. Если некоторые коллокации представляют собой кальки с греческого языка, то другие возникают в рамках древнерусской фразеологической системы. Автор подчеркивает, что только масштабное корпусное исследование позволит составить точное представление об эволюции исторической фразеологии с учетом ее диахронической изменчивости.

Итак, рецензируемый сборник может быть полезен и интересен специалистам по самым разным аспектам русистики: в нем нашли место работы по морфологии и словообразованию, лексической и грамматической семантике, синтаксису и лингвистике конструкций. При этом особенно ценно, что подобный «взгляд со стороны» позволяет заметить неочевидные для русскоязычного исследователя нюансы в языковом материале. Хочется отметить удачный и плодотворный подход, основанный на комплексном учете морфологического, синтаксического и семантического аспектов анализа, и пожелать авторам-составителям продолжения этой просветительской работы, в равной степени востребованной французским и русским читателем.

Сведения об авторе:

Варвара Максимовна Амеличева, канд. филол. наук

доцент

филологический факультет

МГУ имени М.В. Ломоносова
Varvara M. Amelicheva, $\mathrm{PhD}$

Associate Professor

Philological Faculty

Lomonosov Moscow State University

varvara.amelicheva@gmail.com 